\title{
Raven Outside Witchcraft Museum
}

The raven turned, and offered up an eye, The blue-black of his shoulder like a drape That shivered with a sorcerer's escape,

Or with the layered look of poetry.

One thing could be another thing, or allThe way the eye could speak for who he was, While being grounded in the physical.

Between the two was metamorphosis.

He perched on suvs where families thrilled To watch him preen. A horn, and then he rose, His movements like the putting on of clothes. The poem is like this: both the moment stilled, And all anticipation hanging there.

The poem's the raven once he's in the air. 